Revista Brasileira de Farmacognosia Brazilian Journal of Pharmacognosy 21(5): 864-868, Sep./Oct. 2011

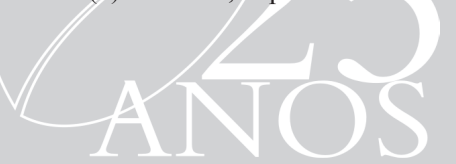

Article

Received 29 Nov 2010

Accepted 8 Mar 2011

Available online 6 May 2011

Keywords:

Casearia lasiophylla

Salicaceae

essential oil

germacrene D

$\beta$-caryophyllene

antitumor

ISSN 0102-695X

http://dx.doi.org/10.1590/S0102-

$695 \times 2011005000073$

\section{Chemical composition and cytotoxic activity of the essential oil from the leaves of Casearia lasiophylla}

\author{
Marcos José Salvador, ${ }^{* 1}$ João Ernesto de Carvalho, ${ }^{2}$ Alberto \\ Wisniewski-Jr, ${ }^{3}$ Candida A. L. Kassuya, ${ }^{4}$ Élide P. Santos, ${ }^{5}$ \\ Dilamara Riva, ${ }^{6}$ Maria Élida Alves Stefanello ${ }^{6}$
}

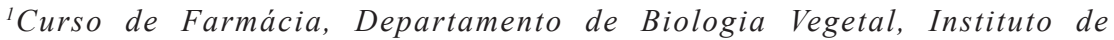 \\ Biologia, Universidade Estadual de Campinas, Brazil, \\ ${ }^{2}$ Centro Pluridisciplinar de Pesquisas Químicas, Biológicas e Agrícolas, \\ Universidade Estadual de Campinas, Brazil, \\ ${ }^{3}$ Departamento de Química, Universidade Federal de Sergipe, Brazil, \\ ${ }^{4}$ Faculdade de Ciências da Saúde, Universidade Federal da Grande \\ Dourados, Brazil, \\ ${ }^{5}$ Departamento de Botânica, Universidade Federal do Paraná, Brazil, \\ ${ }^{6}$ Departamento de Química, Universidade Federal do Paraná, Brazil.
}

\begin{abstract}
The essential oil obtained by hydrodistillation from fresh leaves of Casearia lasiophylla Eichler, Salicaceae, was analyzed by gas capillary (GC/FID and $\mathrm{GC} / \mathrm{MS}$ ). The cytotoxicity of the leaves essential oil was tested in vitro against U251 (glioma), UACC-62 (melanoma), MCF-7 (breast), NC1-ADR/RES (ovarianresistant), NCI-H460 (lung), PC03 (prostate), OVCAR-3 (ovarian), HT-29 (colon) and K562 (leukemia) human cancer cells and against VERO (no cancer cell). The yield of oil was $0.02 \%$. Fifty two compounds were identified, representing $87.1 \%$ of the total of the oil. The main components were identified as germacrene $\mathrm{D}(18.6 \%)$, $\beta$-caryophyllene (14.7\%), $\delta$-cadinene (6.2\%), and $\alpha$-cadinol $(5.4 \%)$. The oil exhibited antiproliferative activity against all cell lines (TGI $<100 \mu \mathrm{g} / \mathrm{mL})$, with exception of NCI-H460 cell line (TGI $191.31 \mu \mathrm{g} / \mathrm{mL}$ ). The highest activity was observed against UACC-62 (TGI $7.30 \mu \mathrm{g} / \mathrm{mL}$ ), and K562 (TGI $7.56 \mu \mathrm{g} / \mathrm{mL}$ ) cell lines. The observed activity could be related to high content of germacrene $\mathrm{D}$ and $\beta$-caryophyllene, compounds known as cytotoxic.
\end{abstract}

\section{Introduction}

Casearia species (Salicaceae) have been used in folk medicine in Brazil against snakebite and for the treatment of skin diseases and ulcers. Several pharmacological activities have been demonstrated to species of this genus, including anti-inflammatory, anti-ulcer and antitumor (Santos et al., 2010; Vieira Jr et al., 2009; Flausino Jr et al., 2009). Previous chemical analyses of Casearia have demonstrated the occurrence of clerodane diterpenoids with cytotoxicity against several human cancer cell lines (Santos et al., 2010; Vieira Jr et al., 2009; Silva et al., 2009; Chen et al., 2008; Sertiè et al., 2000).

The essential oils of Casearia spp analyzed to date are rich in sesquiterpenes (De Morais et al., 1997; Esteves et al., 2005; Schneider et al., 2006; Sousa et al., 2007; Silva et al., 2008; Stefanello et al., 2010) and one sample showed cytotoxic activity (Silva et al., 2008). Casearia lasiophylla Eichler, known as "guaçatunga- graúda" is a tree native from Brazil for which no chemical or pharmacological evaluation has previously been reported. It has been used in folk medicine to treat wounds (Pedroso et al., 2007; Keller \& Tressens, 2007). This prompted us to investigate the chemical and biological properties of this plant.

As part of a research project focusing on phytochemical investigation of Brazilian medicinal plants searching for new bioactivity of natural products, in this study, we report the chemical analysis of the essential oil of $C$. lasiophylla by capillary GC/FID and GC/MS, with the identification of fifty-two compounds. Moreover, the cytotoxic activity of this essential oil against human cancer cell lines is also reported.

\section{Materials and Methods}

\section{Plant material}

The leaves of Casearia lasiophylla Eichler, 
Salicaceae, were collected in Colombo, Paraná State, Brazil. A voucher specimen (Santos $1250 \mathrm{UPCB}$ ) is deposited in the herbarium of Universidade Federal do Paraná.

\section{Isolation and chemical analysis of the essential oil}

Fresh leaves were subjected to hydrodistillation for $2 \mathrm{~h}$. The oil was recovered with diethyl ether and dried over anhydrous sodium sulfate. The solvent was removed under vacuum, providing colorless oil with yield $(\mathrm{w} / \mathrm{w})$ of $0.02 \%$. The oil was maintained under refrigeration before analysis. The GC analysis was performed on a Shimadzu GC-17A gas chromatograph with FID detector, in a split injector mode. A DurabondDB5 capillary column $(30 \mathrm{~m} \times 0.25 \mathrm{~mm}, 0.25 \mu \mathrm{m}$ film thickness) was operated at $60{ }^{\circ} \mathrm{C}$ for $3 \mathrm{~min}$, and then programmed from $60-220^{\circ} \mathrm{C}$ at $5^{\circ} \mathrm{C} / \mathrm{min}$, after which it was kept isothermal at $220^{\circ} \mathrm{C}$ for $5 \mathrm{~min}$. The carrier gas was helium $(1 \mathrm{~mL} / \mathrm{min})$ and the injector temperature was $250^{\circ} \mathrm{C}$. The relative percentage of individual components is based on the peak areas obtained by electronic integration without FID response factor correction. The GC/EIMS (70 eV) analysis was performed on a Varian Saturn $2000 \mathrm{GC}$ / MS spectrometer equipped with a CPSil-8CB capillary column $(30 \mathrm{~m} \times 0.25 \mathrm{~mm}, 0.25 \mu \mathrm{m}$ film thickness) under the same conditions described above. The essential oil components were identified by comparison of their retention indices relative to n-alkanes (Kovat's index) and mass spectra with those found in the literature (Adams, 2007) and stored on the spectrometer database (NIST 1998). In addition, the compounds limonene, eugenol, methyl salicilate, $\beta$-caryophyllene, $\alpha$-humulene and spathulenol were confirmed by comparison with standards.

\section{Antiproliferative assay}

Cell lines: U251 (glioma, CNS), UACC62 (melanoma), MCF-7 (mama), NCI-ADR/RES (ovarian-resistent), NCI-H460 (lung, no small cells), PC-3 (prostate), OVCAR-3 (ovarian), HT-29 (colon), K562 (leukemia) and VERO cell lines, from American Type Culture Collection (ATCC), were used. The assay was done as described previously (Skehan et al., 1990). Briefly, the cells were distributed in 96-well plates (100 $\mu \mathrm{L}$ cells/well) and exposed to various concentrations of essential oil $(0.25,2.5,25.0$ and $250.0 \mu \mathrm{g} / \mathrm{mL})$ in DMSO $(0.1 \%)$ at $37{ }^{\circ} \mathrm{C}$, with $5 \%$ of $\mathrm{CO}_{2}$, for $48 \mathrm{~h}$. The final concentration of DMSO did not affect the cell viability. A 50\% trichloroacetic acid solution was added and after incubation for $30 \mathrm{~min}$ at $4{ }^{\circ} \mathrm{C}$, the cells were washed and dried. Cell proliferation was determined by spectrophotometric quantification (at $540 \mathrm{~nm}$ ) of the cellular protein content using sulforhodamine B. The experiments were carried, at least, in triplicate and the concentration necessary to total growth inhibition (TGI) was calculated in $\mu \mathrm{g} / \mathrm{mL}$. Doxorubicin was used as positive control.

\section{Statistical analysis}

Triplicates from at least three separate experiments were employed in each of the antiproliferative assays. An exploratory data analysis was performed initially to determine the most appropriate statistical test; the assumptions of equality of variances and normal distribution of errors were also checked. The relative potency was based on the drug concentration that inhibited cell growth by $50 \%$ (IC50) [calculated from $[(T-T 0) /(C-T O)] \times 100=50$, which is the drug concentration resulting in a $50 \%$ reduction in the net cell number of drug-treated cultures relative to the increase in control cultures during the drug incubation period]. The data were analyzed using ANOVA and the F-test used to determine any difference among the groups. When significant differences were detected, pair wise comparisons were made between all the groups using Tukey's method to adjust for multiple comparisons. Statistical software GraphPad prism 2.01 (GraphPad Software, San Diego, CA) was used to perform the analyses. The level of significance was set at $5 \%$.

\section{Results and Discussion}

The oil obtained by hydrodistillation from fresh leaves of $C$. lasiophylla was characterized by high content of cyclic sesquiterpenes (86.4\%), mainly hydrocarbons (59.9\%). Monoterpenes (limonene), aromatic compounds (mesitylene, methyl salicilate, eugenol), and aliphatic compounds (isopentyl acetate) were found as minor constituents. Altogether sixtyfour components were observed, of which fifty two were identified, representing $87.1 \%$ of the total of the oil (Table 1). The main constituents were germacrene D $(18.6 \%), \quad E$-caryophyllene $(14.7 \%), \quad \delta$-cadinene (6.2\%), and $\alpha$-cadinol $(5.4 \%)$. The predominance of sesquiterpene hydrocarbons in the leaves essential oil of Casearia species has been previously observed (Stefanello et al., 2010; Silva et al., 2008; Sousa et al., 2007; Schneider et al. 2006; Esteves et al., 2005; De Morais et al., 1997). In particular, E-caryophyllene was found in all samples as a main component (more than $10 \%)$.

The oil exhibited antiproliferative activity for almost all cell lines evaluated, with TGI varying from 7.30 to $55.26 \mu \mathrm{g} / \mathrm{mL}$, with exception of NCI-H460 cell line, for which the TGI was $191.31 \mu \mathrm{g} / \mathrm{mL}$. The most significant activity was observed against UACC-62 
(TGI $7.30 \mu \mathrm{g} / \mathrm{mL}$, melanoma) and K562 (TGI $7.56 \mu \mathrm{g} /$ $\mathrm{mL}$, leukemia). For VERO cell (non-cancer cell-line) the TGI estimated was $65.80 \mathrm{mg} / \mathrm{mL}$, about 8.5 times larger than the TGI of the melanoma and leukemia cell lines, for which the essential oil showed the major bioactivity (Table 2). The coefficients of variation obtained in these analyses were below to $5 \%$. Among the identified sesquiterpenes, germacrene $\mathrm{D}, E$-caryophyllene and $\alpha$-cadinol are recognized as cytotoxic and, could explain the observed activity (He et al., 1997; Silva et al., 2008; Loizzo et al., 2008; Palazzo et al., 2009). The oil of Casearia sylvestris also has high content of $E$-caryophyllene (18.1\%) and showed similar cytotoxic activity agains HT-29 cell line (Silva et al., 2008).

Table 1. Chemical composition of Casearia lasiophylla leaf essential oil.

\begin{tabular}{|c|c|c|}
\hline Component ${ }^{\mathrm{a}}$ & $\mathrm{RI}^{\mathrm{b}}$ & Percentage $(\%)$ \\
\hline Isopentyl acetate & 879 & 0.3 \\
\hline $\mathrm{NI}(m / z 91,105,120)$ & 892 & $\operatorname{Tr}$ \\
\hline $\mathrm{NI}(m / z 91,105,120)$ & 957 & $\operatorname{Tr}$ \\
\hline Mesitylene & 994 & 0.1 \\
\hline Limonene $^{c}$ & 1027 & 0.1 \\
\hline Methyl salicilate ${ }^{c}$ & 1192 & 0.1 \\
\hline $\mathrm{NI}(m / z 73,149)$ & 1299 & $\operatorname{Tr}$ \\
\hline $\mathrm{NI}(m / z 77,93,105,121)$ & 1329 & $\operatorname{Tr}$ \\
\hline$\delta$-Elemene & 1332 & 0.9 \\
\hline$\alpha$-Cubebene & 1344 & 0.1 \\
\hline Eugenol $^{\mathrm{c}}$ & 1353 & 0.1 \\
\hline$\alpha$-Copaene & 1373 & 0.4 \\
\hline$\beta$-Bourbonene & 1380 & 0.1 \\
\hline$\beta$-Cubebene & 1385 & 0.2 \\
\hline$\beta$-Elemene & 1387 & 1.5 \\
\hline$E$-Caryophyllene ${ }^{\mathrm{c}}$ & 1417 & 14.7 \\
\hline$\beta$-Copaene & 1427 & 2.2 \\
\hline$\alpha$-Guaiene & 1432 & 2.6 \\
\hline$\alpha$-Humulene ${ }^{c}$ & 1452 & 2.8 \\
\hline allo-Aromadendrene & 1457 & 0.4 \\
\hline cis-Muurola-4(14), 5-diene & 1470 & $\operatorname{Tr}$ \\
\hline$\gamma$-Gurjunene & 1473 & 1.1 \\
\hline Germacrene D & 1479 & 18.6 \\
\hline$\beta$-Selinene & 1484 & 0.7 \\
\hline cis- $\beta$-Guaiene & 1488 & 0.8 \\
\hline Bicyclogermacrene & 1493 & 1.8 \\
\hline$\alpha$-Muurolene & 1496 & 1.0 \\
\hline trans- $\beta$-Guaiene & 1499 & 1.0 \\
\hline$\gamma$-Cadinene & 1511 & 0.5 \\
\hline$\delta$-Cadinene & 1516 & 6.2 \\
\hline Zonarene & 1521 & 0.4 \\
\hline
\end{tabular}

\begin{tabular}{|c|c|c|}
\hline trans-Cadina-1,4-diene & 1530 & 0.3 \\
\hline$\alpha$-Cadinene & 1534 & 0.2 \\
\hline Germacrene B & 1556 & 2.4 \\
\hline Maaliol & 1567 & 0.6 \\
\hline Spathulenol $^{\mathrm{c}}$ & 1575 & 1.6 \\
\hline Caryophyllene oxide & 1578 & 1.7 \\
\hline Globulol & 1585 & $\operatorname{Tr}$ \\
\hline $\mathrm{NI}(m / z 135)$ & 1587 & $\operatorname{Tr}$ \\
\hline Salvial-4(14)-en-1-one & 1590 & 0.1 \\
\hline Carotol & 1592 & 2.5 \\
\hline Cubeban-11-ol & 1594 & 0.8 \\
\hline Guaiol & 1600 & 0.3 \\
\hline 5-epi-7-epi- $\alpha$-Eudesmol & 1605 & 0.6 \\
\hline Humulene epoxide II & 1607 & 0.1 \\
\hline NI $(m / z 69,161,179)$ & 1613 & $\operatorname{Tr}$ \\
\hline $\mathrm{NI}(m / z 79,91,105,123)$ & 1616 & $\operatorname{Tr}$ \\
\hline Junenol & 1619 & 1.6 \\
\hline 10-epi- $\gamma$-Eudesmol & 1622 & 0.8 \\
\hline 1-epi-Cubenol & 1626 & 2.8 \\
\hline $\mathrm{NI}(m / z 91,105,119)$ & 1628 & $\operatorname{Tr}$ \\
\hline cis-Cadin-4-en-7-ol & 1633 & 0.6 \\
\hline epi- $\alpha$-Cadinol & 1641 & 1.8 \\
\hline epi- $\alpha$-Muurolol & 1644 & 4.8 \\
\hline$\alpha$-Muurolol & 1647 & 0.1 \\
\hline$\alpha$-Cadinol & 1655 & 5.4 \\
\hline Selin-11-en- $4 \alpha$-ol & 1659 & $\operatorname{Tr}$ \\
\hline $\mathrm{NI}(m / z 123)$ & 1672 & $\operatorname{Tr}$ \\
\hline Khusilol & 1680 & $\operatorname{Tr}$ \\
\hline 2,3-Dihydrofarnesol & 1689 & $\operatorname{Tr}$ \\
\hline Eudesm-7(11)-en-4-ol & 1696 & 0.3 \\
\hline NI $(m / z 71,81,95,123)$ & 2109 & 1.0 \\
\hline $\mathrm{NI}(m / z 73,221,355,429)$ & 2262 & 7.6 \\
\hline $\mathrm{NI}(m / z 73,221,355,429)$ & 2576 & 4.3 \\
\hline
\end{tabular}

Total identified (\%) 87.

NI: not identified; tr: trace $(<0.05 \%)$; ${ }^{\text {TTentative identification based }}$ on computer matching of the mass spectra of peaks with NIST 98 library and published data (Adams, 2007), besides comparison of retention indices on published data (Adams, 2007). ${ }^{b} R I$ Retention index relative to $n$-alkanes on a DB- 5 column. 'Identification based on retention time of authentic compounds on the DB- 5 column.

Despite the cytotoxic activity of the essential oil of C. lasyophylla is lower than that of the positive control (doxorubicin), the present results reveal the antitumor potential of this species. The presence of significant amounts of unidentified compounds in the oil that could be contributing to bioactivity points 
out the need of phytochemical studies in this species, aiming at the isolation and identification of its secondary metabolites.

Table 2. Antiproliferative activity of Casearia lasiophylla leaves essential oil.

\begin{tabular}{lcc}
\hline \multirow{2}{*}{ Cell lines } & \multicolumn{2}{c}{ TGI $(\mu \mathrm{g} / \mathrm{mL}) *$} \\
\cline { 2 - 3 } U251 & Essential oil & Doxorubicin \\
UACC-62 & 7.39 & 0.12 \\
MCF-7 & 40.72 & $<0.025$ \\
NCI-ADR/RES & 43.32 & 0.25 \\
NCI-H460 & 191.31 & 2.26 \\
PC-3 & 36.97 & 1.17 \\
OVCAR-3 & 29.49 & 0.40 \\
HT-29 & 55.26 & 0.28 \\
K562 & 7.56 & 3.04 \\
VERO & 65.80 & 0.15 \\
\hline
\end{tabular}

*TGI: Total growth inhibition - concentration that inhibited cell growth by $100 \%$. The coefficients of variation obtained in these analyses were below to $5 \%$. Cell lines: U251 (glioma); UACC-62 (melanoma); MCF7 (breast); NCI-ADR/RES (ovarian-resistent); NCI-H460 (lung); PC03 (prostate); OVCAR-3 (ovarian); HT-29 (colon); K562 (leukemia); VERO (no cancer cell).

\section{Acknowledgements}

The authors are grateful to CNPq, FAPESP and FAEPEX-UNICAMP for financial support.

\section{References}

Adams RP 2007. Identification of Essential Oils Components by Gas Chromatography/Mass Spectroscopy. Allured Publishing Corporation: Carol Stream, IL, USA.

Chen C, Cheng Y, Chen S, Chien C, Kuo Y, Guh J, Khalil AT, Shen Y 2008. New bioactive clerodane diterpenoids from the roots of Casearia membranacea. Chem Biodiv 5: 162-167.

De Morais SM, Machado MIL, Machado SMF, Facundo VA, Militão JSLT, Ribeiro AA 1997. Essential oil of Casearia grandiflora Camb. J Essent Oil Res 9: $697-$ 698.

Esteves I, Souza IR, Rodrigues M, Cardoso LGV, Santos LS, Sertié JAA, Perazzo FF, Lima LM, Schneedorf JM, Bastos JK, Carvalho JCT 2005. Gastric antiulcer and anti-inflammatory activities of the essential oil from Casearia sylvestris SW. J Ethnopharmacol 101: 191196.

Flausino Jr. O, Abissi BM, Vieira Jr GM, Santos AG, Silva, DH, Cavalheiro A, Bolzani VS 2009. Protease inhibition activity of extracts from Salicaceae species from Brazilian cerrado and Atlantic rain forest and an enriched fraction of clerodane diterpenes (casearins). Rev Bras Farmacogn 19: 755-758.

He K, Lu Z, Shi G, Zhao G, Kozlowski JF, McLaughlin JL 1997. Bioactive compounds from Taiwania cryptomerioides. J Nat Prod 60: 38-40.

Keller AH, Tressens SG 2007. Presencia en Argentine de dos especies de uso multiple: Acca sellowiana (Myrtaceae) y Casearia lasiophylla (Flacourtiaceae). Darwiniana 45: 204-212.

Loizzo MR, Tundis R, Menichini F, Saab AM, Statti GA, Menichini F 2008. Antiproliferative effects of essential oils and their major constituents in human renal adenocarcinoma and amelanotic melanoma cells. Cell Prolif 41: 1002-1012.

Palazzo MC, Agius BR, Wright BS, Haber WA, Moriarity DM, Setzer WN 2009. Chemical compositions and cytotoxic activities of leaf essential oils of four Lauraceae tree species from Monteverde, Costa Rica. Rec Nat Prod 3: 32-37.

Pedroso K, Watzlawick LF, Oliveira NK, Valério AF, Gomes GS, Silvestre R 2007. Levantamento de plantas medicinais arbóreas e ocorrência em Floresta Ombrófila Mista. Ambiência 3: 39-50.

Santos AG, Ferreira PMP, Vieira-Junior GM, Perez CC, Tininis AG, Silva GH, Bolzani VS, Costa-Lotufo LV, Pessoa, CO, Cavalheiro AJ 2010. Casearin X, its degradation product and other clerodane diterpenes from leaves of Casearia sylvestris: evaluation of cytotoxicity against normal and tumor human cells. Chem Biodiv 7: 205-215.

Schneider NFZ, Moura NF, Colpo T, Flach A 2006. Composição química e atividade antimicrobiana do óleo volátil de Casearia sylvestris Swart. Rev Bras Farm 87: 112-114.

Silva SL, Chaar JS, Figueiredo PMS, Yano T 2008. Cytotoxic evaluation of essential oil from Casearia sylvestris $\mathrm{Sw}$ on human cancer cells and erythrocytes. Acta Amaz 38: 107-112.

Silva SL, Chaar JS, Yano T 2009. Chemotherapeutic potential of two gallic acid derivative compounds from leaves of Casearia sylvestris Sw (Flacourtiaceae). Eur J Pharmacol 608: 76-83.

Sertiè JAA, Carvalho JCT, Panizza S 2000. Antiulcer activity of the crude extract from leaves of Casearia sylvestris. Pharm Biol 38: 112-119.

Skehan P, Storeng R, Scudiero D, Monks A, McMahon J, Vistica D, Warren JT, Bokesch H, Kenney S, Boyd MR 1990. New colorimetric cytotoxicity assay for anticancer-drug screening. J Natl Cancer Inst 82: 1107-1118.

Sousa FG, Schneider NFZ, Mendes CE, Moura NF, Denardin RBN, Matuo R, Mantovani MS 2007. Clastogenic and anticlastogenic effect of the essential oil from Casearia sylvestris Swart. J Essent Oil Res 19: 376378. 
Stefanello MEA, Wisniewski-Jr A, Simionatto EL, Cervi AC 2010. Essential oil composition of Casearia decandra Jacq. J Essent Oil Res 22: 157-158.

Vieira Jr GM, Gonçalves TO, Regasini LO, Ferreira PMP, Pessoa CO, Lotufo LVC, Torres RB, Boralle N, Bolzani VS, Cavalheiro AJ 2009. Cytotoxic clerodane diterpenoids from Casearia obliqua. J Nat Prod 72: 1847-1850.

\section{*Correspondence}

Marcos José Salvador

Curso de Farmácia, Departamento de Biologia Vegetal, Instituto de Biologia, Universidade Estadual de Campinas Caixa Postal 6109, 13083-970 Campinas-SP, Brazil marcosjs@unicamp.br

Tel.: +551935216167

Fax: +551935216184 